\title{
Editorial: The Trust of the People of Canada
}

Three scant months after the Government accepted the Nansen Medal on behalf of the People of Canada, it has negated the

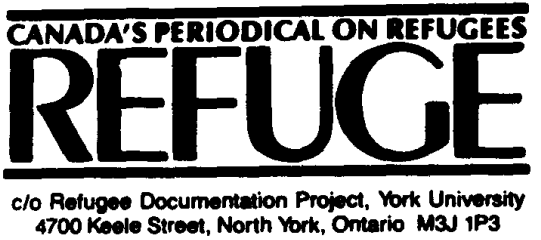

Guest Editors:

Christina Lee

Penny Van Esterik

Editor:

C. Michael Lanphier

Feature Editor:

Alex Zisman

Managing Editor:

Noreen Nimmons

Editorial Assistant:

Alice Dinerman

Refuge is dedicated to the encouragement of assistance to refugees by providing a formm for sharing information and opinion on Canadian and international isaes pertaining to refugees. It is published four times a year by the Refugee Documentation Project. It is a non-profit, independent periodical supported by private donations and by subscriptions. It is a form for discussion. and the views expressed do not necessarily reflect those of its funders or staff.

All materials in Refuge may be reproduced without permission unless copyrighted or otherwise indicated. Credit shoull be given to the author or source, if named.

Subscription rates for one year are $\$ 20.00$ in Canada and US\$20.00 overseas. Please enclose payment with your order.

Logo design:

Dreadnaught Co-operative Inc., Toronto

Socond Cese Mill Regidration No. 5512 LSSN 0229-5113 very spirit of its entitlement. The recent series of measures restricting refugeeclaimant inflow tells us more about the government's hyper-sensitivity to criticism than its attempt to govern with compassion through informed selfconscious policy.

There is little doubt that Canada has experienced a sudsen influx in asylum claimants in recent months, especially. since Jaruary. Instead of devising ways to assist provincial governments and nongovernmental organizations who have taken the lion's share of the tasks of accommodation and support, it thas opted to satisfy the carping criticism of those sectors having least contact with refugees and to restrict future entry.

While the stress on persecuted peoples throughout the world is increasing, Canada has scrapped the list of "protected" country origins facilitating rapid and safe entry, and instead twisted visa, transit visa and summary return regulations into a tangle of bureaucratic red tape which leads asylum-seekers back to the very countries which had imperiled their protection!

None of the problems of demand for asylum in Canada is solved, and more are made. With the backlog of claimants already approaching 20,000 people for the refugee determination process, the government has decided to add more to the queue by requiring those formerly admissible on Minister's permits now to join the file. On paper this appears as a streamlining into a single process. In practice it has inundated a system already overflowing with cases. Chaos in the name of efficiency!

Even more potentially dangerous for would-be claimants (mainly Salvadoreans and Guatemalans) seeking asylum by crossing the border from the U.S., claimants must retum to the U.S. to await a hearing. Nothing more than a verbal undertaking from the U.S. Immigration and Naturalization Service (INS) assures protection of these would-be claimants in the U.S. until a Canadian hearing is scheduled. The INS is notorious for failing to protect people whom it classifies as "economic migrants" - codeword for Salvadoreans and Guatemalans. This is one area of foreign relations which requires independence from intervention by, or compliance with U.S. immigration authority.

Recall that the distinguishing feature of refugee policy from immigration policy in general is the focus on humanitarian concerns - which by their very nature transcend national interest. In such light, reaction to waves of public concern over alleged abuses of administrative and operational policies for refugee intake should represent only a surface manifestation to alert government as to whether its humanitarian policy is being correctly understood or implemented. Careful reflection is required on issues which become political because of unmet needs. No better example can be found than the contents of this copy of Refuge, devoted to refugee women. As editors Lee and Van Esterik demonstrate in these pages, gender issues are often ignored and easily bypassed. It is the caring government that seeks to be responsive to its less privileged members - no less true in the global community than within our borders.

The federal government has compounded problems in its already formidable agenda of inland refugee determination. It has instead devised ad-hoc ways and means to keep as many asylum seekers as possible away from Canadian borders. Canada distances itself while people fleeing persecution wait in uncertain if not unprotected circumstances. Canada has opted to protect its borders rather than refugees. We urge the government to turn back to compassion. In so doing, it will return to its true role of policy-making.

C. Michael Lanphier Howard Adelman 